\title{
PERAN ORGANISASI DALAM DAKWAH
}

\author{
P-ISSN: 2085-4536 | E-ISSN: 2721-7183 \\ Link: https://jurnal-stidnatsir.ac.id/index.php/binaummat/article/view/52 \\ DOI : https://doi.org/10.38214/jurnalbinaummatstidnatsir.v2i02.52 \\ Dikirim: 25-03-2019 \\ Direview: 05-04-2019 \\ Diterbitkan: 17-04-2019 \\ AHMAD MISBAHUL ANAM \\ misbahulanam@stidnatsir.ac.id \\ STID Mohammad Natsir - Indonesia
}

\begin{abstract}
ABSTRAK
Tujuan Penelitian: Untuk mengetahui peran organisasi dalam dakwah. Metode Penelitian: Kualitatif. Hasil Penelitian: Dalam khazanah Islam, aktifitas da'wah selalu memiliki kaitan dengan media da'wah. Dalam penelitian ini media da'wah yang akan menjadi obyel kajian adalah keberadaan lembaga Dewan Da'wah Islamiyah Indonesia dan apa perannya sehingga dianggap masih relevan ditengah da'wah yang masiv melalui perorangan. Pada kasus gugatan terhadap UU Nomor 1/PNPS/1965 terlihat peran lembaga ini sangat penting, karena selain berperan melindungi umat dari kerusakan akidah, tapi juga berusaha untuk mempertahankan kebijakan pemerintah dari gugatan pembatalan. Secara kelembagaan Dewan Da'wah telah memerankan keberadaannya dengan berbagai peran yang strategis. Diantara temuan penelitian ini, peran lembaga tersebut mewujud sebagai dinamisator, konsolidator, komunikator, peredam konflik sosial serta peran eksistensialisme simbolik. Dalam pembahasan ini, peneliti menggunakan pendekatan peran sebagai sarana membedah obyek kajian.
\end{abstract}

Kata kunci: Peran, organisasi, lembaga da'wah

\section{PENDAHULUAN}

Da'wah telah menjadi tren tersendiri dalam era digital hari ini, seiring dengan mudahnya akses dan teknologi yang disediakan. Bahkan membuat setiap orang menjadi lebih dekat dengan kegiatan da'wah dan sekaligus menjadi pelakumya, bahkan hanya dengan dirinya sendiri, tanpa bantuan kepanitian dan lembaga pelaksana yang harus dibuat terlebih 
dahulu. Fasilitas media komunikasi memungkinkan hal tersebut dengan alat yang smart dan model kegiatan da'wah yang bervareasi. Fenomena ini seperti antitesa dengan da'wah konvensional yang memerlukan banyak orang terlibat sebagai panitia pengelola program dan sangat tergantung dengan berbagai keterlibatan banyak hal.

Menurut Abdul Karim Zaidan, "Media da'wah dalam bentuk organisasi (jam'iyyah), bekerjasama dengan orang lain dalam menyebarkan ajaran Islam dan dalam da'wah, memerlukan pengetahuan yang luas, kesabaran, mmpersiapkan dirinya untuk berbuat taat, menekan perasaan, menyingkirkan kepentingan-kepentingan pribadi, merendahkan diri, dapat memahami dan mengerti kepentingan orang lain dan dengan demikian itu barulah dapat bekerjasama dengan orang lain. Disamping itu dia harus bersedia menerima pendapat orang lain yang berbeda dengan pendapatnya sendiri dan bersedia menerima ketetapan yang ditetapkan oleh pimpinan""

Hari ini, jika kita ingin berdakwah dan diakses oleh jama'ah maka semuanya bisa disediakan dalam media online, kapan saja dan dimana saja. Chanel-chanel da'wah sangatlah banyak dan mudah untuk dibuat, seiring dengan keinginan setiap aktivitis Islam untuk ikut terlibat dalam arena ini. Media da'wah konvensional dalam bentuk organisasi da'wah berbadan hukum mulai ditinggalkan, karena rumit dan boros pembiayaan. Ada juga yang berpandangan, karena lembaga da'wah dalam bentuk organisasi seperti hari ini, tidak ada dalam kehidupan Nabi maka dianggap suatu hal baru (bid'ah) yang harus ditinggalkan. Pro-kontra dalam sekup yang kecil terjadi antara da'wah jam'iyyah (organisasi) dan fardiyah (individu), mana yang lebih penting, atau mana yang harus ditinggalkan dan mana yag harus diambil. Jika ditelusuri lebih dalam, dengan mengesampingkan pro-kontra diatas sekurangnya dengan meletakkan hal terbut sebagai media pilihan dalam da'wah, tentu kita bisa melihat peran masing-masingnya dalam aktivitas da'wah dengan melihat luasnya cakupan dan obyek da'wah yang ada.

Suatu ciri khas dari tradisi keislaman adalah kepercayaan bahwa Islam merupakan sebuah pandangan hidup yang menyeluruh dan terpadu. Agama mempunyai suatu hubungan yang integral dan organik dengan politik dan masyarakat. Cita-cita keislaman itu tercermin dalam

\footnotetext{
${ }^{1}$ Abdul Karim Zaidan, Dasar-dasar IImu Dakwah, Media Da'wah, Jakarta, hlm. 254255
} 
perkembangan hukum Islam yang merupakan sebuah hukum terpadu, yang mencakup kewajiban-kewajiban seorang Muslim kepada Tuhan (shalat, haji, zakat, puasa) dan kewajiban-kewajiban kepada sesama manusia (hukum perdagangan, keluarga dma pidana). Oleh karena itu, tradisi Islam menawarkan suatu sistem normatif dimana agama adalah integral dengan semua aspek kehidupan Muslim, sepertu dalam hal politik, ekonomi, hukum, pendidikan dan keluarga ${ }^{2}$.

Aspek kemasyarakatan dalam hal ini politik telah banyak mengambil peran sentral bersinggungan dengan konsep Islam. Apalagi setelah wafatnya Nabi, maka eskalasi politik khususnya dalam hal penggantian kepemimpinan, telah menyisakan sedikit kisah yang menyedihkan, walaupun sangatlah banyak lagi kebaikan-kebaikan dari kepemimpinan Islam dalam bentuk lahirnya hukum-hukum baru. Yurisprudensi hukum menjadi cara masyarakat Islam melakukan ijtihad. Nah! Pada proses ijtihad inilah peran kepemimpinan dalam hal ini putusan khilafah Islam banyak mengambil peran. Memang ada musyawarah dan masukan dari para ahli, tetapi keputusan diambil berdasar sikap dari khalifah sebagai pemegang otoiritas kekuasaan kepemimpinan. Maka, dalam teori hukum Islam memilih pemimpin yang baik menjadi perhatian yang serius dan penting, walaupun tetap saja ada yang tidak memuaskan. Bahkan ada juga gerakan pembangkangan terhadap khalifah dan undangundangnya. Kita bisa temui misalnya pada masa Khalifah Umar, lahir nabi palsu dan gerakan pemurtadan.

Dalam sistem politik modern, sisa-sisa perlawanan terhadap konstitusi negara tidak saja bersifat fisik berupa pemberontakan, tapi juga masuk lewat kontruksi hukum. Bahkan, eskalasi anti moral, semakin mendapatkan celah yang prospek seiring dengan kecenderungan wujudnya negara sekular termasuk didalamnya ideologi ateisme. Jika kita mengikuti karya-karya yang menyinggung pembahasan epistimologi perang peradaban khususnya pada tema ghazwu al-fikr, maka tawaranya adalah sekularisasi pada semuah aspek kehidupan. Bahasa sederhananya, "sekular adalah keniscayaan dalam perilaku pemerintah dan kebijakan yang dihasilkannya". Dengan ungkapan kesombongan, "berikan hak Kaisar kepada Kaisar dan berikan hak Gereja kepada Gereja", kepedulian yang merusak tatanan. Nilai-nilai agama tak usah masuk dalam kehidupan

\footnotetext{
2 John L. Esposito, Agama dan Perubahan Sosiopolitik, Aksara Persada, 1985, hlm. 1
} 
kenegaraan. Padahal kehidupan bernegara memerlukan etika dan moral, tidak sekedar estetika dan rasionalitas. Ketuhanan Yang Maha Esa, membingkai kesadaran negara hukum Negara Kesatuan Republik Indonesia warisan para perintis kemerdekaan sebagai acuan dalam mengatur kehidupan berbangsa dan bernegara.

Memang ada semacam kutukan demokrasi, bahwa konsekweksi logis -tapi dipaksakan- dalam negara modern yang demokrasi, semua suara akan diberikan tempat yang sama. Nilai orang baik dan orang jelek sama, tiada perbedaan dimata negara demokrasi. Akibatnya, kalolah pada awalnya ada kebijakan yang telah ditetapkan, maka pada suatu saat akan dapat dituntut untuk dicabu, ataupun direvisi, tentunya tetap melalui proses yang panjang untuk sampai pada diputuskan. Kebebasan dijadikan jargon dan stimulus agar ada kesan, bahwa pelakunya termasuk memiliki kepentingan yang sama. Kebijakan negara yang dilahirkan tidak lagi menjadi budaya mengadili, tapi hanya ingin dijadikan dasar bahwa dengan kedudukan yang sama setiap insan memiliki hak yang sama dalam berbagai aspek.

Melihat fenomena kemasyarakat yang politis seperti ini, gerakan da'wah memang tidak bisa lagi hanya berhenti pada aspek tabligh, hanya menyampaikan ajakan saja dengan media fardiyah (peronal) tanpa didukung oleh entitas sosial berupa lembaga berbadan hukum yang legal. Binaan (membina) saja ternyata tidak cukup dalam da'wah dengan basis pribadi, tapi juga harus ada difa'an (pertahanan) yang berbentuk badan hukum sebagai konsekwensi logis dari konsep imamah, syura, jama'ah, comunitas (qaryah thayyibah) dan lain-lain. Karena sebagai makhluk sosial, pastilah interaksinya tidak sebatas pada hal-hal individu, tapi juga menyangkut hajat orang banyak yang dalam hal ini wujudnya bisa berupa kemungkaran konstitusi atau kebijakan politik yang tidak adil. Kondisi seperti ini, berkonsekwensi terhadap wujudnya pertahanan da'wah dalam bentuk lembaga legal yang bisa dan mampu "bertarung" dalam lapangan legislasi. Walaupun tidak menafikan adanya fenomena da'wah fardiyah dengan media sosial sebagai patner da'wah yang telah menjadi pilihan personal menyampaikan pesan-pesannya dengan mudah, tidak serepot mengurus da'wah melalui lembaga.

Urgensi lembaga dalam kegiatan da'wah dalam kontek kebijakan undang-undang bisa kita ambil contoh saat Ahmadiyah yang diwakili oleh beberapa aktivisnya mencoba menggugat kedudukan UU Nomor 1/PNPS/1965 yang mengatur tentang pencegahan dan penodaan agama. 
Harapannya! Jika gugatan diterima dan undang-undang dibatalkan, maka akan ada kebebasan dan jaminan hukum terhadap fenomena penyebaran kesesatan yang sangat mendasar "akidah". Respon gugatan yang diajukan ke MK oleh Ahmadiyah segera ditangkap oleh Dewan Da'wah sebagai lembaga yang konsen terhadap fenomena kerusakan akidah. Dalam misinya memang memasukkan aspek akidah sebagai usaha penguatan ummat.

Permohonan pengujian Undang-undang Nomor 1/PNPS/1965 oleh perorangan yang mengatas namakan komunitas Ahmadiyah telah dilakukan sebanyak tiga kali pada tahun 2009, 2012 dan 2017 dengan tujuan pembatalan undang-undang tersebut karena dianggap telah melanggar HAM dan diskriminatif. Pokok permohonan pengujian terkait pasal 1, 2 dan 3 UU Pencegahan Penodaan Agama, yang berbunyi ;

Pasal 1 berbunyi,

"Setiap orang dilarang dengan sengaja di muka umum menceritakan, menganjurkan atau mengusahakan dukungan umum, untuk melakukan penafsiran tentang sesuatu agama yang dianut di Indonesia atau melakukan kegiatan-kegiatan keagamaan yang menyerupai kegiatan-kegiatan keagamaan dari agama itu; penafsiran dan kegiatan mana menyimpang dari pokok-pokok ajaran agama itu".

Pasal 2 berbunyi,

(1) Barang siapa melanggar ketentuan tersebut dalam pasal 1 diberi perintah dan peringatan keras untuk menghentikanperbuatannya itu di dalam suatu keputusan Menteri Agama, Menteri/Jaksa Agung dan Menteri Dalam Negeri.

(2) Apabila pelanggaran tersebut dalam ayat (1) dilakukan oleh Organisasi atau sesuatu aliran kepercayaan, maka Presiden Republik Indonesia dapat membubarkan Organisasi itu dan menyatakan Organisasi atau aliran tersebut sebagai Oraganisasi/aliran terlarang, satu dan lain setelah Presiden mendapat pertimbangan dari Menteri Agama, Menteri/ Jaksa Agung dan Menteri Dalam Negeri.

Pasal 3 berbunyi,

"Apabila setelah dilakukan tindakan oleh Menteri Agama bersama-sama Menteri/Jaksa Agung dan Menteri Dalam Negeri atau oleh 
Presiden Republik Indonesia menurut ketentuan dalam pasal 2 terhadap orang, Organisasi atau aliran kepercayaan, mereka masih terus melanggar ketentuan dalam pasal 1, maka orang, penganut, anggota dan/atau anggota Pengurus Organisasi yang bersangkutan dari aliran itu dipidana dengan pidana penjara selama-lamanya lima tahun".

Pasal-pasal inilah yang dikatakan komunitas Ahmaduyah sebagai pokok pengujian dalam laporannya. Para pihak yang terkait dengan pengajuan ini terdiri dari dua kubu, satu kubu yang pro dengan Ahmadiyah yaitu meminta pembatalan UU tersebut dan yang kontra yakni yang tetap mendukung adanya UU ini sebagai sarana pengaturan atas masalah pencegahan dan penodaan Agama. Dua arus mainstrem pihak terkait yang pro Ahmadiyah adalah Yayasan Lembaga Bantuan Hukum Indoesia (YLBHI) dan Komisi Nasional Anti Kekerasan terhadap Perempuan (Komnas Perempuan) dan yang kontra disuarakan oleh Dewan Da'wah Islamiyah Indonesia (DDII) dan Majlis Ulama Indonesia (MUI). Para pihak ini memiliki kedudukan yang sah didepan hukum (legal standing) dalam forum Mahkamah Konstitusi.

Dalam keterangan para pihak terkait, UU ini memiliki hubungan dengan sila pertama, "Ke-Tuhanan Yang Maha Esa" yang tidak bisa dipisahkan dengan Agama. Dimana dalam negara hukum menempatkan nilai-nilai agama melandasi gerak kehidupan bangsa dan negara, bukan negara yang memisahkan hubungan antara agama dan negara serta tidak semata-mata berpegang pada prinsip individual dan prinsip komunisme.

Penelitian ini akan mengungkap bagaimana lembaga da'wah, maksudnya suatu entitas da'wah dalam bentuk organisasi legal mengambil peran dalam sengketa konstitusi didepan MK terhadap suatu undangundang yang menguntungkan kegiatan da'wah, melawan para penggugat. Untuk melihat urgensi da'wah dalam bentuk organisasi, peneliti mengaitkan dengan posisi Dewan Da'wah sebagai lembaga berbadan hukum sebagai pihak terkait dalam hal permohonan warga negara Indonesia selaku penganut komunitas Ahmadiyah yang menganggap menjadi korban pemberlakuan UU No 1/PNPS/1965. Komunitas tersebut memohon kepada MK sebagai pihak pemutus tingkat pertama dan terakhir untuk melakukan pengujian undang-undang tersebut sebagai pihak penggugat. Sedang DDII bertindak mengkanter permohonan didepan mahkamah, untuk meyakinkan agar UU tersebut tetap ada. Dalam 
penelitian ini tidak menyinggung materi, isi dan argumentasi secara detail sebagai suatu peristiwa di dalam forum terhormat, kecuali hanya sebatas mencupliknya untuk memberikan bahan keterangan bahwa banyak peran lembaga da'wah terkait dengan masalah tersebut. Peran-peran inilah yang coba digali, sehingga didapatkan penjelasan yang utuh.

Peran diartikan dengan melakukan sesuatu yang menjadi bagian dalam terjadinya sesuatu hal atau peristiwa (KBBI), atau fungsi. Dalam fenomena sosial peran bisa didudukkan sebagai media penyambung, terhubungnya dua atau berbagai peristiwa yang sedang terjadi. Peran memiliki sifat aktif, makanya dalam peritiwa drama, term peran biasa dinisbatkan kepada sang pelaku, misal dalam kalimat, "ia berperan sebagai bintang tamu". Ada beberapa teori terkait dengan term "peran" yang bisa dijelaskan dalam kaitanya dengan hubungan sosial bermasyarakat (sosiologis). Suatu lembaga berperan memberikan advokasi hukum, artinya lembaga tersebut berfungsi sebagai pelayan masyarakat dalam hal pendampingan hukum.

Sedangkan yang dimakasud dengan lembaga atau organisasi (badan) adalah perkumpulan orang untuk tujuan melakukan suatu usaha bersama ${ }^{3}$. Dalam tradisi peradaban Islam, keberadaan lembaga sebenarnya tidak semata-mata sebagai media penyelenggara da'wah, tapi juga difahami sebagai sarana menjalankan perintah agama dalam menerjemahkan soal kepemimpinan, dan musyawarah, walaupun tidak sebagaimana yanga ada saat ini. Kita mengenal pembagian tugas, wewenang, pergantian pimpinan perang, tim penulis mushab, lembaga pengelola Masjid dan lain-lain. bentuk-bentuk lembaga tersebut sangat mungkin dipengaruhi oleh pesan surat As-Shaff ayat 4,

"Sesunggubnya Allah menyukai orang yang berperang dijalan-Nya dalam barisan yang teratur seakan-akan mereka seperti suatu bangunan yang tersusun kokoh".

Dengan adanya lembaga sebagai pengelola dan pengatur dinamisasi orang kepentingan serta nilai-nilai yang akan didakwahkan didalamnya, maka tujuan da'wah akan lebih mudah diraih. Hal ini dikarenakan da'wah difahami tidak saja bersifat reaktif terhadap masalah kekinian, tapi juga adanya masalah dan program da'wah yang harus dikelola

\footnotetext{
${ }^{3}$ M. Munir dan Wahyu Ilahi, Manajemen Da'wah, Kencana, Jakarta, 2009, hlm. 118
} 
jangka pendek, menengah dan panjang. Pada aspek-aspek inilah, kelembagan da'wah dapat dipandang memiliki peran-peran yang cukup penting sebagai gerakan dinamis berupa tindakan dan perilaku karena nilainilai yang ada pada individu atau organisasi ${ }^{4}$. Peran sebagai kebijakan yang harus dilaksanakan, peran sebagai strategi untuk mendapatkan dukungan dari masyarakat. Peran sebagai alat komunikasi dan juga sebagai alat pemutus sengketa dalam rangka meredam konflik dan memutuskan suatu masalah di tengah masyarakat ${ }^{5}$. Secara keilmuan peran memiliki kaitan dengan berbagai disiplin ilmu yang terkait dengan psikologis dan juga sosiologis. Walaupun harus mengalami penyesuaian khususnya dalam da'wah, psikologis bisa berperan pada aspek kejiwaan, demikian juga peran sosiologis amat membantu bagaimana da'wah lebih mudah diterima sebagai sarana mengubah suatu kondisi ${ }^{6}$.

Bahan utama dari penelitian ini adalah laporan sidang-sidang dalam bentuk dokumen yang terjadi antara medio 2017-2018 di Mahkamah Konstitusi, dengan menggunakan pendekatan kualitatif. Bahan-bahan referensi yang lain, peneliti mengandalkan dokumen on-line baik diambil dari media masa, jurnal, makalah dan buku online, karena karena harus mematuhi protokol wabah covid-19 untuk mengunjungi perpustakaan.

\section{HASIL DAN DISKUSI}

Sebagai konsekwensi dari keberadaan suatu lembaga da'wah, pastilah tujuan dari pendirianya bermanfaat bagi masyarakat banyak menyangkut tentang perbaikan kualitas Islam sebagai pandangan hidup dan perilaku keseharian. Tujuan tersebut biasanya tertuang dalam visi misi da'wah, yang kemudian menjelma dalaman bentuk lembaga, nilai-niai perjuangan atau pesan, pelaku, obyek, media, dan pengaruh dakwah disusun agar lembaga da'wah dapat memberikan peran yang cukup signifikan bagi perubahan masyarakat. Peran lembaga da'wah dalam diskursus wacana kegiatan yang masif, yang dikelola dalam bentuk lembaga berbadan hukum menjadi suatu fenomena tersendiri, apalagi jika lembaga

\footnotetext{
${ }^{4}$ http://repository.uinsu.ac.id/4828/5/Bab\%20II.pdf, diakses pada 14 Mei 2020

${ }^{5}$ http://repo.iain-tulungagung.ac.id/7911/5/BAB\%20ll.pdf, diakses pada 14 Mei 2020

${ }^{6}$ http://ejournal.uin-suka.ac.id/dakwah/jurnaldakwah/article/download/315, diakses pada 14 Mei 2020
} 
itu memiliki cabang di tingkat Kota/kabupaten, unit-unit program dan jangkauan yang luas. Ia akan merespon isu global dan nasional, tanpa melupakan isu lokal sehari-hari. Dengan cakupan yang luas inilah, menjadikan Dewan Da'wah sebagai sebuah lembaga da'wah berusaha memaksimalkan peran-peran yang lebih strategis terhadap problem keummatan baik dalam bentuk binaan maupun difaan ${ }^{7}$. Problem keumatan yang tidak saja pada aspek pembinaan, tapi juga aspek pertahanan (difa'an), melindungi dan menjaga nilai yang telah dibina. Penelitian ini lebih menyoroti bagaimana lembaga ini merespon problem difa'an, khususnya pada kasus kebijakan undang-undang yang dianggap sentral dalam melindungi akidah dan keyakinan umat beragama di Indonesia. Kasus yang dibahas adalah dalam persoalan gugatan terhadap UU Nomor 1/PNPS/ 1965 tentang Pencegahan Penyalahgunaan dan/atau Penodaan Agama oleh Komunitas Ahmadiyah. Dalam gugatanya komunitas tersebut mendalilkan bahwa UU ini perlu dihapus karena telah membatasi kebebasan seseorang dalam beragama. Perlu juga dicatat, bahwa Ahmadiyah adalah satu gerakan yang lahir di India dan menjadikan Mirza Ghulam Ahmad sebagai nabi dengan kitabnya $A t$-Tad₹kirah ${ }^{8}$, sementara ajaran Islam telah menetapkan Nabi terakhir adalah Muhammad Rasulullah dengan membawa wahyu Al-Qur'an dan berbangsa 'Arab.

Dewan Da'wah sebagai lembaga da'wah memanfaatkan posisinya sebagai legal standingnya (badan hukum publik) berusaha memberikan peran yang maksimal dalam hal peran difa'an, mempertahankan posisi undang-undang tersebut tetap berlaku sebagai pihak terkait didepan Mahkamah Konstitusi. Posisi sebagai pihak terkait dalam gugatan tersebut, karena Dewan Da'wah ingin menjalankan peran dan fungsinya sebagai penegak syari'ah, pengawal akidah, perekat ummat,

\footnotetext{
${ }^{7}$ Khittah Da'wah Dewan Da'wah yang diterbitkan lembaga ini sebagai acuan visi misinya.

${ }^{8}$ Untuk lebih mendalaminya tentang Ahmadiyah dalam versi Indonesia bisa mendalaminya dalam Fatwa MUI tahun 2005 bahwa Ahmadiyah adalah sesat diluar Islam, juga tulisan Amin Jamaludin LPPI suatu lembaga yang mengkhususkan dalam penelitian aliran-aliran sesat yang berkembang di Indonesia. Terkait Ahmadiyah, LPPI pernah melaporkan jemaah Ahmadiyah ke Polisi saat dengar pendapat dengan DPR sebanyak 3 kali 2006, 2009 dan 2011 dengan tuntutan telah melakukan penistaan terhadap agama Islam ( tempo.co, edisi 7 Maret 2011)
} 
menjaga martabat bangsa dan membangun solidaritas dunia Islam². Disini terlihat adanya peran aktif yang sangat menonjol terutama pada aspek pertahanan, pembelaan atau biasa disebut dalam hasanah Islam dengan istilah difa'an, dimana keberadaan lembaga dalam kontek relasi dengan pemerintah maupun masyarakatnya memiliki posisi hukum dalam sengketa tersebut. Posisi ini dimanfaatkan untuk menguatkan UU Nomor 1/PNPS/1965 karena didalamnya menyangkut hajat penyelamatan keyakinan Agama atas suatu nilai penodaan agama yang merupakan persoalan serius karena dapat merusak tatanan agama dan merusak kondusivitas keberagamaan masyarakat. Undang-undang ini juga untuk memudahkan pihak pemerintah dan juga lembaga Agama dalam merespon potensi yang akan merusak akidah dengan dalih kebebasan berekspresi dan mengeluarkan pendapat. Pun, dengan UU Nomor 1/PNPS/1965 ini sebenarnya juga akan memberikan jaminan keamanan bagi setiap pemeluk agama dari provokasi anarkis, dan adanya kesadaran berbagai pihak untuk berhati-hati dalam membuat pernyataan, aktifitas dan gerakan yang berpotensi menyinggung keyakinan agama.

Penelitian ini sengaja dilakukan untuk melihat seberapa penting peran da'wah dalam bentuk lembaga dalam ikut serta memasyarakatkan nilai-nilai Islam sehingga terwujud masyarakat agamis dan menjadikan Islam sebagai pandangan hidupnya. Apalagi jika merunut sejarah perjuangan intelegnesia Muslim di Indonesia, keberadaan lembaga pembinaan Islam telah lahir sebelum Indonesia merdeka. Keberadaan Serikat Dagang Islam, Muhamadiyah, NU, Persis, Al-Irsyad menjadi cikal bakal da'wah Islam melalui lembaga. Tak terhitung lagi lembaga-lembaga da'wah setelah era kemerdekaan, dimana salah satunya adalah Dewan Da'wah Islamiyah Indonesia yang lahir pada tahun 1967. Lembagalembaga seperti ini dalam sistem demokrasi adalah bagian dari civil society dengan istilah organisasi non-pemerintah (ornop), dimana mereka menikmati hak-hak politik, hal sipil dan otonomi organisasi, sementara pemerintahan menjalankan kekuasaan yang akuntabel berdasar hasil pemilu ${ }^{10}$. Keberadaan lembaga da'wah dimaksudkan sebagai patner dalam ikut serta mengatur masyarakat dengan dasar nilai-nilai agama yang diakui di Indonesia. Kedinamisan lembaga da'wah sebagai pembina masyarakat bukan partisan, dimana tujuannya adalah utamanya adalah memperbaiki

\footnotetext{
${ }^{9}$ AD/ART Dewan Da'wah Islamiyah Indonesia.

${ }^{10}$ https://jurnal.ugm.ac.id/jsp/article/view/11072/8313
} 
kondisi, sehingga satu waktu boleh jadi melakukan kontrol tapi satu waktu melakukan penguatan, baik kepada masyarakat ataupun kepada pemerintah. Peran penguatan dalam penelitian ini menjadi fokus bahasan, dimana keberadaan lembaga da'wah menguatkan kebijakan pemerintah dalam hal ini UU Nomor 1/PNPS/1965 karena isinya adalah perlindungan terhadap nilai-nilai keyakinan sebagaimana kepentingan da'wah Islam ini sendiri. Penguatan kebijakan ini dilakukan karena adanya gugatan pembatalan undang-undang ini oleh komunitas Ahmadiyah yang keberadaannya sudah dinilain sesat berdasar Fatwa MUI 2005 serta larangan beroperasi di Indonesia dan juga negara-negara di Timur Tengah. Apa saja peran lembaga da'wah menghadapi kondisi seperti ini. Setelah melakukan berbagai cara memahami kegiatan lembaga dalam kasus ini, ternyata ditemukan beberapa fakta lapangan banyak sekali peran-peran positif berdakwah melalui lembaga atau organisasi. Berikut ini akan dipaparkan berbagai peran tersebut.

Pertama, peran dinamisator, dimana lembaga melibatkan dirinya dalam suatu sengketa dengan pihak lain pada suatu peristiwa hukum di Mahkamah Konstitusi. Menggerakkan ingatan orang tentang kepentingan bersama melindungi keyakinan agama yang sedang mendapatkan ancaman perusakan. Peran ini tergambar secara jelas dalam tujuan lembaga ini didirikan yaitu berperan sebagai penegak syari'ah, pengawal akidah, perekat ummat. Sendi syari'ah (ajaran) harus ditegakkan tidak saja dalam kontek tabligh, tapi juga dalam wilayah hukum, karena bentuk negara hukum ini sendiri menuntut adanya peran dari masyarakat. Ajaran agama tidak berdiri sendiri bersifat privat (pribadi-pribadi) tapi juga masuk wilayah publik, dimana maksud dari tujuan syari’at adalah wujudnya kebahagiaan bersama. Apalagi, sengketa hukum yang digugat adalah persoalan yang mendasar yaitu akidah, nilai dasar dan inti pada suatu keyakinan yang telah mendapatkan jaminan eksistensinya dari undang-undang. Menjaganya berarti memberikan respon konstruktif sebagaimana pemohonan yang dalam hal ini Ahmadiyah meminta pembatalan undang-undang yang mengatur tentang penodaan dan pelecehan agama atau UU No. 1/PNPS/1965.

Peran Dewan Da'wah ketika terlibat dalam masalah sengketa hukum ini, menjadi pihak terkait dalam usaha merekatkan ummat untuk tidak terlibat gerakan diluar hukum, dimana hal tersebut justru akan memberikan dampak yang tidak baik kepada masyarakat dan kepada Islam 
ini sendiri. Cara ini ditempuh sebagai cara konstitusional sehingga yang akan memberikan putusan, pengawasan dan pembinaan adalah negara, dimana negara adalah melindungi warganya. Cara cerdas ini selain konteknya adalah difa'an, juga untuk memberikan pembinaan kepada ummat atau jama'ah bahwa manakala ada sengketa hendaklah ditempuh secara legal melalui lembaga yang sah, tidak main hakim sendiri. Dalam bahasa da'wahnya ada aspek tandhiman (legal hukum yang berlaku) pada suatu wilayah, tanpa meninggalkan aspek syariah (nilai-nilai dasar agama) sebagai pedoman dalam gerak da'wah. Mengaitkan masalah da'wah dengan aturan negara adalah suatu bukti bahwa Dewan Da'wah adalah lembaga legal yang menghormati kebijakan negara dalam bentuk undang-undang dan sejenisnya dan juga dapat menepis tuduhan-tuduhan yang negatif seperti gerakan subversif, terorisme dan makar terhadap pemerintah. Peran-peran ini barangkali juga dipengaruhi oleh para pendirinya yang juga banyak terlibat dalam penderian Negara Kesatuan Republik Indonesia, dimana Mohammad Natsir pernah duduk sebagai Perdana Menteri, Syafruddin Prawiranegara (Menku), Prawoto Mangkusasmito (MA), Mohammad Rasyidi (Menag pertama) dan beberapa tokoh nasional yang lainya.

Dewan Da'wah juga terlihat melakukan peran kontrol terhadap kebijakan yang dibuat oleh negara. Dalam sengketa di MK ini, perhatian lembaga berusaha untuk menjeburkan diri melakukan pengawalan UU No. 1/PNPS/1965 sebagai payung hukum terhadap suatu kenyataan destruktif lapangan, yaitu adanya indikasi dan gerakan perusak dasar-dasar suatu keyakinan. Karena jika, UU No.1/PNPS/1965 ini dibatalkan dalam suatu proses hukum yang legal, maka konsekwensinya adalah tiadanya perlindungan hukum terhadap keyakinan. Setiap individu bebas melakukan pelecehan dan penodaan agama tanpa harus beresiko berurusan dengan hukum, atau dengan kata lain, justru individu yang melakukan penodaan (malah) mendapatkan perlindungan hukum. Atau malah, orang atau lembaga yang membela keyakinannya akan dipersalahkan, kondisi dibuat netral tidak ada yang benar dan yang salah. Jika perlindungan hukum hilang, maka gerakan masa akan merugikan stabilitas kehidupan bernegara dan bermasyarakat. Maka peran mengawal kebijakan yang telah menjadi konstitusi negara menjadi penting, karena sejatinya yang dapat melaksanakan agama atau memaksa nilai-nilai agama sebagai wujud dari 
dasar negara Berketuhanan Yang Maha Esa adalah negara itu sendiri dan inilah fungsi negara hukum yang baik.

Kedua, peran konsolidatif atau ukbuwah (persaudaraan), dimana lembaga da'wah sejatinya adalah lembaga yang memiliki peran perekat (ukhuwah) terhadap kepentingan Islam dan misi lembaga sejenisnya serta menumbuhkan partisipasi dari masyarakat luas sebagai anggota maupun simpatisanya. Keterlibatan lembaga dalam urusan-urusan mendasar dan umum ini akan menumbuhkan solidaritas jama'ah untuk banyak terlibat dalam program-program da'wahnya. Apalagi jika kita mengaca pada landasar dibentuknya suatu lembaga ummat adalah mewujudkan ukhuwah persatuan ummat baik tingkat lokal, nasional dan internasional, karena umat Islam adalah ummat yang satu. Kesatuan ummat ini direkat dengan akidah, tauhid yang satu. Dalam peritiwa sengketa ini, Dewan Da'wah sejalan juga dengan tanggapan dan reaksi masyarakat terhadap gerakan Ahmadiyah yang mengembangkan ajaran dan faham tersebut dalam bentuk sikap dan aksi penolakan. Penolakan dan pelarangan kegiatan juga dilakukan oelh sejumlah kepala daerah ; Subang Jabar (1976), Sidrap Sulsel (1986), Kerinci Jambi (1989), Bulungan Kaltim (1989), Sumut (1994), Pasaman Barat (2001), Lombok Timur NTB (2002), Kuningan Jabar (2004) dan Tasikmalaya Jabar (2005) ${ }^{11}$.

Penolakan atas pelecehan dan penodaan yang dilakukan Ahmadiyah, adalah juga konsekwensi dari Fatwa MUI Nomor 11/MUNAS/VII/MUI/15/2005 yang menyatakan : (1) Menegaskan kembali keputusan fatwa MUI dalam Munas II tahun 1980 yang menetapkan bahwa Aliran Ahmadiyah berada di luar Islam, sesat dan menyesatkan, serta orang Islam yang mengikutinya adalah murtad (keluar dari Islam), (2) Bagi mereka yang terlanjur mengikuti Aliran Ahmadiyah supaya segera kembali kepada ajaran Islam yang haq (al-ruju' ila al-haq), yang sejalan dengan al-Qur'an dan al-Hadist, dan (3) Pemerintah berkewajiban untuk melarang penyebaran faham Ahmadiyah di seluruh Indonesia dan membekukan organisasi serta menutup semua tempat kegiatanya.

Peran konsolidasi dalam sengketa ini juga bisa ditelusuri dari banyaknya lembaga da'wah yang tergabung dalam Forum Ukhuwah

${ }^{11}$ Putusan MK Nomor 56/PUU-XV/2017, hlm. 110-113 
Islamiyah $(\mathrm{FUI})^{12}$. Terlibat juga para ahli dan pakar terkait yang dipersengketakan untuk memberikan kajian dan pandangannya terkait dengan nilai-nilai kesesatanya ataupun kesalahan-kesalahan terkait dengan aspek hukum dan sosiologisnya. Dalam sidang tersebut Dewan Da'wah mengajukan 6 ahli yaitu M Amin Djamaluddin, Daud Rasyid Sitorus, Abdul Chair Ramadhan, Amidan Shaberah, Musni Umar dam Yusril Ihza Mahendra. Para ahli ini menyerahkan keteranganya baik secara lisan ataupun tertulis dibawah sumpah dalam persidangan tersebut ${ }^{13}$.

Beberapa kenyataan diatas dapat dijadikan sandaran, bahwa suatu lembaga da'wah dalam hal ini Dewan Da'wah telah berada dalam kepentingan yang sama, baik dengan keyakinan yang benar dari masyarakat, visi dan misi lembaga da'wah yang lain dan kepentingan pemerintah sebagai pihak yang legal untuk melaksanakan kebijakan negara. Isu-isu yang memiliki dampak yang luas dan menyangkut undang-undang negara, menjadi lebih efektif untuk dirawat dalam rangka menumbuhkan gerakan konsolidasi bersama, sehingga masing-masing lembaga tidak hanya sibuk dengan urusannya sendiri dengan program-program da'wah yang telah di rancang. Aspek konsolidasi, atau ukhuwah harus menjadi prioritas bersama, satu diantaranya adalah bersama-sama menangani hal-hal yang secara kepentingan adalah misi bersama.

Ketiga, peran komunikatif, dimana lembaga da'wah da'wah memerankan keberadaannya sebagai sumber informasi yang otoritatif bisa dipertanggung-jawabkan baik secara isi maupun akibat hukum yang ditimbulkan. Peran ini juga bisa menjadi acuan dan contoh kepada jama'ah bagaimana mengatasi masalah-masalah khususnya yang berkaitan dengan materi hukum di depan pengadilan. Peristiwa hukum seperti ini akan mengedukasi masyarakat agar tidak gampang melakukan aksi-aksi masa yang boleh jadi akan meningkatkan emosi jamaah yang sulit diatasi. Apa yang dilakukan lembaga da'wah yang mau bersengketa didepan pengadilan ini juga bermanfaat pada tumbuhkan kesan positif dimata pemerintah dan masyarakat bahwa umat Islam selalu menghormati hukum dan mau terlibat didalamnya. Menghilangkan kesan sebelumnya, seakan lembaga da'wah itu

\footnotetext{
12 Putusan MK Nomor 56/PUU-XV/2017, hlm. 113. FUI adalah perkumpulan lembaga-lembaga da'wah Islam di Indonesia, dimana dalam forum inilah lembagalembaga melakukan musyawarah terkait masalah da'wah.

13 ibid, hlm. 172
} 
dibuat hanya untuk kepentingan sendiri, tertutup, tidak egaliter dan tidak profesional. Peran inklusif seperti ini harus terus dimainkan oleh lembaga da'wah, sehingga akan menumbuhkan kesadaran masyarakat luas bagaimana membangun komunikasi dengan pihak luar, dan ini adalah ciri Islam yang rahmatan lil'alamin.

Keempat, peran peredam konflik sosial. Dalam budaya sosial, masyarakat biasanya berkumpul dalam berbagai bentuk komunitas karena kepentingan dan tujuan yang sama. Lembaga da'wah juga demikian, memeliki visi, misi dan tujuan yang sama antar orang-orang yang terlibat. Bahkan, antar lembaga da'wah pun, jika diperhatikan, bahwa masingmasing lembaga selalu mencantumkan nilai-nilai mulia dari Islam sebagai basis pergerakanya, bahwa lembaga dibuat untuk menjaga nilai dasar Islam yaitu akidah. Dengan satunya akidah, maka akan memudahkan sebuah konflik yang ada dalam masyarakat Islam ditangani. Ada patokan dasar untuk kembali (ruju') ke jalan yang benar. Dimana lembaga bisa melakukan inisiasi melakukan dialog langsung terhadap sebuah fenomena sosial, baik mewakili dirinya ataupun menjadi pihak terkait sebagaimana dalam kasus gugatan di pengadilan. Pada kasus gugatan pembatan UU Nomor 1/PNPS/1965 Dewan Da'wah secara kelembagaan memposisikan diri sebagai legal standing ikut berperkara dalam pengadilan MK dengan peran sebagai pihak terkait untuk menguatkan posisi UU dan melemahkan argumentasi hukum yang diajukan pihak penggugat.

Keterlibatan lembaga dalam hal ini adalah melindungi mayoritas keyakinan Muslimin untuk tidak bertindak main hakim sendiri karena adanya ancaman pencabutan UU penodaan. Konflik sosial akan hilang dengan sendirinya, karena dengan eksisnya UU tersebut akan mendorong pemerintah melakukan menertiban berdasar perintah konstitusi. Bisa dibayangkan! Seandainya UU tersebut dicabut maka sama saja akan mengundang konflik berkepanjangan karena tidak adanya pembatasan atas kebebasan yang merusak keyakinan. Secara sosial, fenomena yang paling sulit didamaikan adalah persoalan yang menyangkut keyakinan. Apalagi jika yang bermasalah adalah sama-sama soal keyakinan, yang satu memiliki keyakinan sesat tentang masih adanya nabi palsu setelah nabi terakhir, yang satunya meyakini Nabi yang benar berdasar argumen-argumen yang kuat berupa Wahyu, Hadist, sejarah dan silsilah yang dapat dipercaya keotentikannya. 
Bisa difahami memang peran lembaga sosial dalam hal ini lembaga da'wah tentu memiliki konstribusi, karena wilayah garapanya adalah pada aspek kejiwaan. Jika negara biasanya menangani wilayah formil, maka lembaga da'wah menangani aspek material yaitu nilai, equal dengan dasar negara berdasar Ketuhanan Yang Maha Esa, yang memiliki nilai satunya keyakinan tentang keesaan. Dalam wacana Islam, selain pengakuan Tuhan Yang Esa, ditambah dengan paket satunya keyakinan bahwa Nabi terakhir penutup semua utusan adalah Muhammad saw. Dua hal ini adalah diantara paket doktrin yang harus diyakini umat Islam seluruh dunia dalam kerangka Rukun Iman dan menjadi dasar indikator apakah seseorang tersebut berada dalam barisan Islam atau ada diluar. Rukun Iman menyatukan perbedaan dan menguatkan kebersamaan.

Perjuangan menguatkan undang-undang ini sebagai sarana pengaturan masyarakat senada dengan pesan Natsir, "Tiap-tiap manusia mempunyai dorongan kuat untuk mempertahankan kehidupan dan menjamin kelanjutan jenisnya dengan melengkapi hajat-hajat hidupnya, yang primer dan selanjutnya untuk mempertinggi taraf kehidupannya sebagai manusia. Ini fitrah" ${ }^{\prime 14}$. Pada aspek material kebutuhan primer manusia adalah makan, sedang dalam gerakan da'wah kebutuhan primernya adalah nilai-nilai ideologis yaitu terjaminnya keimanan. Gangguan keimanan akan menstimulus munculnya perlindungan dan perlawanan terhadap entitas yang kontra. Maka, bisa difahami mengapa lembaga ini mengambil peran dalam kasus tersebut.

Kelima, peran eksistensialisme simbolik, dimana sebuah lembaga perlu melakukan aksi nyata untuk meneguhkan keberadaannya (eksistensinya) dalam pergulatan persoalan yang menyangkut hajat da'wah itu sendiri, baik pada level lokal maupun global dalam bentuk peran aktif dimasyarakat. Pada kasus ini, peran aktif yang dilakukan adalah ikut terlibat dalam perkara pengadilan dalam kasus gugatan UU nomor 1/PNPS/1965 oleh komunitas Ahmadiyah. Apalagi pihak penggugat yaitu komunitas Ahmadiyah ternyata juga memiliki jaringan global dan dukungan politik yang kuat, dari kawasan Eropa khususya Inggris. Dalam kegiatan komunikasi, suatu simbol memerankan eksistensi tentang siapa dirinya kepada kalayak sebagai bukti bahwa ia masih ada dan aktif melakukan halhal yang diharapkan oleh para jama'ah. Masyarakat bina'an, terutama para

\footnotetext{
${ }^{14}$ M. Natsir, Fiqh Da'wah, Media Dakwah, Jakarta, 2006, hlm. 41
} 
simpatisan ideologis sangat senang jika simbol hubungan antar mereka menyasar hal-hal yang sangat mendasar, seperti pada kasus diatas. Kesan komunikasinya sangat kuat, karena masuk pada nilai yang paling esensial, soal keyakinan kepada Rasul sebagai media yang merelly pesan dari Allah kepada para pengikutnya. Peran simbolik ini akan semakin bertambah besar kesannya dibenak jama'ah, karena isu-isu yang ditangani ternyata memiliki bobot global.

Simbol dalam bentuk kegiatan ini akan memberikan ketenangan dan kepuasan bagi para jama'ah dan simpatisan, karena mereka merasa dibela kepentingannya dalam menjaga keyakinan. Peran simbolik dalam kasus gugatan ini dalam konsep pewarisan nilai, akan mendistribusikan nilai-nilai positif yang ada pada lembaga sebagai kekayaan sejarah da'wah di Indonesia dan dunia.

Keenam, peran contoh (uswab). Dalam kasus diatas, peran contoh ditampilan dalam keberanian menginisiasi sebagai pihak terkait dengan konsekwensi harus melakukan kajian dengan para ahli, menyiapkan advokat yang membuat pembelaan, menghadirkan saksi ahli dan menghadiri sidang-sidang. Keterlibatan lembaga dalam penanganan kasus seperti ini akan menanamkan kepercayaan, karena masyarakat ataupun lembaga-lembaga sejenis akan terstimulus bagaimana sebaiknya menghadapi kasus-kasus yang menyangkut kebijakan.

Al-Bayanuni menyebutnya dengan konsep qudwah dimana aksiaksi yang dilakukan akan menjadi acuan. Proses qudwah adalah melihat aksi, lalu mencoba (al-hissi : eksperimen) ${ }^{15}$ karena apa yang dilakukan terasa menarik dan memiliki kecocokan nilai. Peran kekuatan qudwah pada kasus ini memiliki korelasi dengan liputan media televisi sebagai berita utama, sehingga ada proses hubungan antara aksi dengan para penonton. Bobot beritanya menjadi menarik karena isunya sensitif, up to date dan ideologis antara yang pro dan kontra.

Dalam dunia komunikasi masa dikenal dengan demonstrasi aksi yang bertujuan untuk meyakinkan audien, diadopsi oleh bagian marketing untuk menggaet pasar yang lebih luas. Kita kenal istilah test drive bagi mobil keluaran terbaru, nyaman atau tidak bagi pembeli. Dalam qudwab juga

${ }^{15}$ https://Academia.edu/40424720/Analisa, diakses pada 19/05/2020 
demikian, apa yang nampak dari pelaku pertama akan dijadikan contoh untuk diikuti.

\section{KESIMPULAN}

Bentuk kelembagaan sebagai media da'wah, sejatinya menjadi satu keniscayaan karena da'wah dalam artian yang luas tidak semata-mata aktivitas menyampaikan dan pembinaan saja. Bahkan, tatkala da'wah dibawa keranah kegiatan kemayarakatan maka interaksi perannya sesungguhnya akan terintegrasi dengan seluruh kehidupan ini sendiri, baik dalam bidang ekonomi, politik dan hukum. Konsekwensi dari ini semua, mengharuskan peran-peran yang konstruktif, berdaya jangkau segala aspek dan menyentuh hajat masyarakat dan pemerintah.

Terkait hal tersebut Dewan Da'wah Islamiyah Indonesia terlihat sekup dan daya jangkaunya sebenarnya khas tetapi luas secara fatsum politik kenegaraan. Kekhasannya terdapat peran dan fungsi lembaga sebagai penegak syari'ah, pengawal akidah, perekat ummat, menjaga martabat bangsa dan membangun solidaritas dunia Islam. Pada kasus gugatan terhadap UU Nomor 1/PNPS/1965 terlihat peran lembaga ini sangat penting, karena selain berperan melindungi umat dari kerusakan akidah, tapi juga berusaha untuk mempertahankan kebijakan pemerintah dari gugatan pembatalan. Bagi Dewan Da'wah, pembelaan terhadap tangantang da'wah bisa dimaknai dengan cara membela keyakinan ummat dan juga pembelaan terhadap UU pemerintah yang menguntungkan pekerjaan da'wah Islam.

Secara organisasi Dewan Da'wah Islamiyah Indonesia telah memerankan fungsi kelembagaan secara strategis berupa keterlibatan dalam aksi konstitusional. Jika dulu pendirinya terlibat diruang parlemen dalam merumuskan kebijakan negara, kini para penerusnya melakunya melalui lembaga yudikatif yaitu Mahkamah Konstitusi. Diantara temuan dalam penelitian ini, peran-peran lembaga yang dapat di mainkan dalah peran sebagai dinamisator, konsolidator, komunikator, peredam konflik sosial, peran eksistensialisme simbolik dan peran qudwab (contoh). Dengan melihat peran yang sangat vareatif tersebut, kita dapat menyimpulkan bahwa kelembagaan da'wah memiliki peran yang signifikan bagi pembinan dan pertahan da'wah di tengah masyarakat yang sangat majemuk. 


\section{DAFTAR PUSTAKA}

Abdul Karim Zaidan, Dasar-dasar Ilmu Dakwah, Media Da'wah, Jakarta $\mathrm{AD} / \mathrm{ART}$ Dewan Da'wah Islamiyah Indonesia

Fatwa MUI tahun 2005

http:/ /ejournal.uinsuka.ac.id/dakwah/jurnaldakwah/article/download/315, diakses pada 14 Mei 2020

http://repo.iain-tulungagung.ac.id/7911/5/BAB\%20II.pdf, diakses pada 14 Mei 2020

http:/ / repository.uinsu.ac.id/4828/5/Bab\%20II.pdf, diakses pada 14 Mei 2020

https://Academia.edu/40424720/Analisa, diakses pada 19/05/2020

https://jurnal.ugm.ac.id/jsp/article/view/11072/8313

John L. Esposito, Agama dan Perubahan Sosiopolitik, Aksara Persada Khittah Da'wah Dewan Da'wah

M. Munir dan Wahyu Ilahi, Manajemen Da’wah, Kencana, Jakarta, 2009

M. Natsir, Fiqh Da’wah, Media Dakwah, Jakarta, 2006

Putusan MK Nomor 56/PUU-XV/2017

tempo.co, edisi 7 Maret 2011) 